In addition to the reports just mentioned. the volume also contains a detailed account of the determination by wireless telegraphy of the difference in longitude between Paris and Bizerta.

Spectrum of Wolf-Rayet StaR D.M. + $30^{\circ} 3639 .-$ Mr. Paul W. Merrill records in the Lick Bulletin, No. 230, the result of the examination of the red end of the spectrum of the Wolf-Rayet star D.M. $+30^{\circ} 3639$, the photographic magnitude of which is $20^{\circ} 0$, and position for I900\% R.A. Igh. 3om. 8s., Dec. $+30^{\circ}$ I $8^{\prime}$. The following previously observed bright lines appear: - $\lambda_{4} 6_{52}$ broad; H $\beta$ monochromatic, strong; $\lambda_{5694}$ broad; $\lambda_{5} 8 \mathrm{r}$ broad, trace; $\mathrm{D}_{3}$ doubtful; $\mathrm{H} \alpha$ monochromatic, strong. In addition to the above, the following two bright lines appear:- $\lambda 654^{\circ} 5$ monochromatic, $0_{4}$ as strong as $\mathrm{Ha} ; \lambda 6_{58} 3^{\circ}$ monochromatic, slightly stronger than $\mathrm{Ha}$. The chief nebular lines are not seen in the star's spectrum. It is pointed out that these two nebular lines were observed by Wright in the nebula N.G.C. 7027, but are otherwise unidentified. While the two lines appear together it does not necessarily follow that their origins are identical.

\section{THE BERLIN MEETING OF THE INTERNATIONAL ELECTROTECHNICAL COMMISSION.}

THE meeting of the International Electrotechnical Commission was held in Berlin at the Kunstlerhaus from September I to September 6. It was well attended, twenty-four nations being represented by seventy delegates. In addition to the voting delegates sent by the local committees of the countries represented, some of the Governments also nominated their official representatives, those representing England being Dr. Glazebrook, who was unfortunately not able to attend, Dr. Gisbert Kapp, Dr. Silvanus P. Thompson, and Mr. Duddell, the president of the Institution of Electrical Engineers. The German Government was represented by Dr. Jaegar, Geheimrat Dr. Strecker, and several others. Unfortunately, Dr. E. Budde, the president of the International Electrotechnical Commission, was absent through illness, but his place was very efficiently filled by Dr. Warburg, the president of the Reichsanstalt.

The commission was welcomed on behalf of the German Grovernment by Dr. Lewald, Director of the Ministry of the Interior. Prof. Paul Janet, of the Laboratoire Centrale, Paris, replied on behalf of the commission.

The proceedings were opened by the reading of the report of the honorary secretary, Col. Crompton, on the work which had been accomplished up to date and confirmed by the last plenary meetings held two years previously at Brussels; he also briefly described the new work which had been prepared during the two years' interval by the various national committees, and by the four special committees which had been appointed to bring forward the four main subjects requiring international treatment; and which required confirmation at this the second plenary meeting, to ensure final acceptance by all the national committees.

The first two days were occupied by the final meetings of the special committees. The first, and certainly the most difficult, question to be decided internationally, was that of providing a means of international rating of electrical machinery. This matter, touching closely as it does on industrial questions, was naturally very warmly debated, both in the meetings of the special committee, which was presided over by Huber Stockar, the well-known Swiss engineer, and at the full meeting, but although much valuable evidence was brought forward on the test methods to be adopted for international rating, the only figures that were unanimously agreed to were the final temperatures permissible in the hottest parts of working generators, motors, and transformers, but the remaining very necessary factors, namely agreement as to temperature-rise and as to the standard temperature of the ambient air from which the temperature-rise must be calculated, were not considered to be sufficiently settled to allow of unanimity.

On the latter point the English and American engineers insisted on taking the ambient air temperature at a figure of $40^{\circ} \mathrm{C}$., which is very frequently obtained at certain times of the year in all tropical and in many temperate climates, especially in enginerooms, stokeholds, and similar places. It will be noted that the choice of this high temperature is greatly to the advantage of a purchaser, as it ensures that a machine ordered on standard international rating will be a somewhat large machine capable of a larger overload in cool weather than was hitherto considered necessary by manufacturers. The majority of the meeting was apparently in favour of adopting this high figure so favourable to the consumer; but the German and Swedish engineers thought that the matter was too important to be decided off-hand, so the filling in of these two figures is left for further consideration by the national committees. It is hoped that an agreement may be arrived at in the course of this year, or at any rate before the next plenary meeting, which is to be held at San Francisco two years hence.

The reports and the recommendations of the three other special committees, first that on nomenclature, second on the international standardisation of symbols in use for formulæ, and third on the definitions and terminology for prime-movers used for electrical generating plant, were all unanimously adopted. It is needless to point out that the unification of symbols is of immense benefit to the engineering student, and the unanimity arrived at by a number of delegates who, in the majority of cases, are largely interested in other branches, and particularly mechanical engineering, makes it probable that this unification of symbols will extend to all branches of engineering science, and perhaps eventually to all branches of physical investigation.

As regards nomenclature, although the work done is undoubtedly good and useful, at first sight it seems small in amount, as a list of only eighty terms with the expressions defining them was adopted. It has been found necessary to modify the original arrangements by which there should be two official languages, English and French, to which others should be referred, but the inconvenience of having two languages of reference was so marked that the English agreed to forego their claim that English should continue to be one of the official languages, French now remains as the one language of reference from which all words and expressions must be translated, but it was decided that the vocabulary which has now been prepared should contain the official corresponding words now agreed to, in four languages-French, English, German, and Spanish. The delegates from five countries using the Spanish language informed the meeting that this unification of terms in the Spanish language would be of great service to them, for already misunderstandings had arisen, as some of the South American countries using the Spanish language had shown a tendency to adopt different Spanish words for one and the same expression.

NO. 229I, VOL. 92] 
Another matter satisfactorily settled was the copper standard, which had long been discussed between the four National Physical Laboratories of England, France, Germany, and America, and the ultimate figures were agreed to, so that the tables of copper conductors based on this standard will be common to all the countries.

Mr. Maurice Leblanc, of Paris, was unanimously elected to succeed Dr. Budde, as president of the I.E.C., for a term of two years, and he will therefore preside at San Francisco.

Colonel Crompton was re-elected honorary secretary for the third time.

The Spanish delegates invited the special committees to hold their next meetings in April next in Madrid, and the Russian delegate, Prof. de Chatelain, on behalf of the Russian Committee, invited the I.E.C. to hold the plenary meeting of I9I7 in St. Petersburg.

\section{BUDGETS OF CERTAIN UNIVERSITIES AND UNIVERSITY COLLEGES IN ENGLAND AND WALES.}

THE reports for the year I9I I-I2 from those univerties and university colleges in Great Britain which are in receipt of grant from the Board of Education have been issued in two bulky volumes (Cd. 7008 and $\mathrm{Cd}$. 7009). The first volume contains reports from the provincial universities and university colleges in England, and the second reports from the London college, including the medical schools, the Welsh colleges, and Dundee University College.

The tabular matter which precedes the separate reports from the various universities contains detailed information as to the income and expenditure of the places of higher education concerned. The following summaries have been compiled from the tables, and show at a glance the amount available for education and research in the universities and colleges receiving Treasury grants and how the income is expended.

\section{Universities and University Colleges.}

\section{(I) ENGLAND.}

\section{(a) Income}

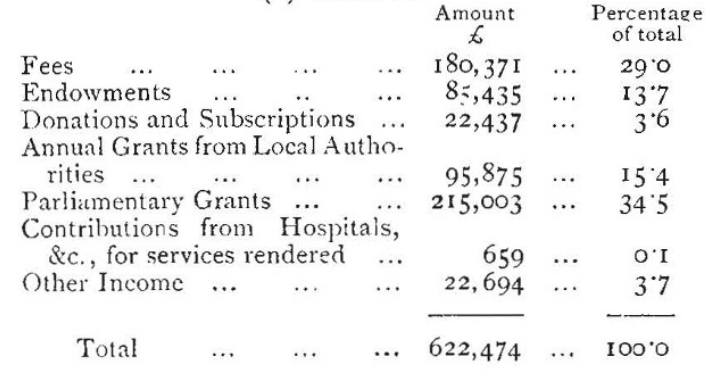

(b) Expenditure.

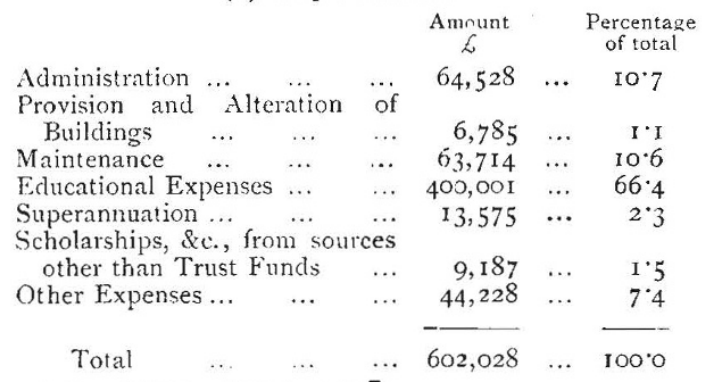

NO. 229I, VOL. 92$]$
(2) Wales.

(a) Income.

\begin{tabular}{|c|c|c|c|c|c|c|}
\hline \multirow[b]{2}{*}{ Fees $\quad \ldots$} & & $\underset{6}{\text { Amount }}$ & \multicolumn{2}{|r|}{$\begin{array}{l}\text { Percentage } \\
\text { of total }\end{array}$} \\
\hline & $\cdots$ & $\ldots$ & $\ldots$ & $18,1+7$ & $\ldots$ & $28 \cdot 2$ \\
\hline Endowments & $\ldots$ & $\ldots$ & $\ldots$ & 4, I9I & $\ldots$ & 6.5 \\
\hline Donations and & Subscri & ptior & as $\ldots$ & I,91 I & $\ldots$ & 3.0 \\
\hline Annual Gra & ts fro & $\mathrm{m}$ & Local & & & \\
\hline Authorities & & $\ldots$ & $\ldots$ & 5,283 & $\ldots$ & $8 \cdot 2$ \\
\hline Parliamentary & Grants & $\ldots$ & $\ldots$ & 33,805 & $\ldots$ & $52 \cdot 7$ \\
\hline Other Income & $\ldots$ & $\ldots$ & $\ldots$ & 890 & $\ldots$ & $1 \cdot 4$ \\
\hline Total & $\ldots$ & $\ldots$ & $\ldots$ & 64,197 & $\ldots$ & $100 \cdot 0$ \\
\hline
\end{tabular}

(b) Expenditure.

\begin{tabular}{|c|c|c|c|c|c|}
\hline Administration $\ldots$ & & & $8, \stackrel{£}{104}$ & $\ldots$ & $\begin{array}{l}\text { of total } \\
\text { I } 2 \cdot 7\end{array}$ \\
\hline Maintenance & $\ldots$ & .. & 4,659 & $\ldots$ & $7: 3$ \\
\hline Educational Expeuses & $\ldots$ & $\ldots$ & 46,399 & .. & $72 \cdot 6$ \\
\hline Superannuation $\ldots$ & $\ldots$ & & 1,640 & ... & $2 \cdot 6$ \\
\hline $\begin{array}{l}\text { Scholarships, \&c., fr } \\
\text { than Trust Funds }\end{array}$ & om & ther & & & 0.6 \\
\hline Other Expenses ... & $\cdots$ & $\cdots$ & 2,670 & $\cdots$ & $4 \cdot 2$ \\
\hline Total & $\ldots$ & $\cdots$ & 867 & $\ldots$ & 0 \\
\hline
\end{tabular}

The total income from endowments in England has increased by about $4500 l$., due chiefly to nerv endowments for Reading University College, which bring in about $4000 l$. a year, and the increased income of about I6ool. a year available for East London College. On the other hand, the income from Welsh endowments has fallen by nearly $300 l$. The total income from donations and subscriptions shows some falling-off, both in England and Wales, owing in part at least to the exclusion of donations specially earmarked for scholarship purposes. The net annual grants from local education authorities show an increase of about 10,oool. in England and about $800 l$. in Wales. The income received from Parliamentary grants increased during the year by about $58,000 l$.

The expenditure during I9II-I2 out of income upon the provision and alteration of buildings in England was more than $4000 l$. greater than in the previous year, owing in the main to heavy expenses at Leeds largely due to the provision of a hostel for women and to alterations and equipment at University College, London.

\section{THE PILTDOWN SKULL}

$\mathrm{I}$ his evening lecture to the British Association at Birmingham on September 16, Dr. Smith Woodward took the opportunity of replying to Prof. Arthur Keith's recent criticisms on his reconstruction of the Piltdown skull. It will be remembered that Dr. Woodward regarded the mandible as essentially that of an ape, and restored it with ape-like front teeth, while he determined the brain-capacity of the skull to approach closely the lowest human limit. Prof. Keith, on the other hand, modified the curves of the mandible to accommodate typically human teeth, and reconstructed the skull with a brain-capacity exceeding that of the average civilised European.

Fortunately, Mr. Charles Dawson has continued his diggings at Piltdown this summer with some success, and on August 30, Father P. Teilhard, who was working with him, picked up the canine tooth which obviously belongs to the half of the mandible originally discovered. This tooth corresponds exactly in shape with the lower canine of an ape, and its worn face shows that it worked upon the upper canine in the true ape fashion. It only differs from the canine of Dr. Woodward's published restoration in being slightly smaller, more pointed, and a little more up- 